\title{
International standards for the regulation of lobbying (EU, CE, OECD, CIS)
}

\begin{abstract}
The article outlines the international standards for the regulation of lobbying. These standards were introduced at four international organizations and supranational associations: 1) the European Union; 2) the Council of Europe; 3) the Organization for Economic Cooperation and Development; 4) the Commonwealth of Independent States. The article states that the key reason for the introduction of standards for the regulation of lobbying at the international level was considerable corruption in the adoption of legal acts. It is concluded that latent and unregulated lobbying can seriously undermine public confidence in the institution of government, especially in the countries of the so-called "new democracy". International regulation of lobbying takes the form of resolutions, procedural rules, guidelines, recommendations and model legislation.

Notably, the first steps towards international regulation of lobbying were taken by the institutions of the European Union. Today EU standards for the regulation of lobbying is based on a series of articles set out in the EU-founding treaties and the Charter of Fundamental Rights of the European Union. EU standards for the regulation of lobbying influence not only the EU Member States, but it also extends to EU Partner Countries. Significant steps in the implementation of international standards for the regulation of lobbying are being constantly carried out by the Council of Europe. The establishment of CE standards for the regulation of lobbying is reflected in the activity of statutory bodies of the Council of Europe and its semi-autonomous bodies. In recent years a lot of work on the strengthening of international standards for lobbying regulation has been done by the Organisation for Economic Co-operation and Development. To help address the concerns with transparency and integrity in lobbying, the OECD Member Countries adopted in 2010 a Recommendation on Principles for Transparency and Integrity in Lobbying
\end{abstract}

Volodymyr Nesterovych - Doctor of Law Sciences, professor of Department of Common Legal Disciplines at Luhansk State University of Internal Affairs named after E.A. Didorenko (Ukraine); e-mail: nesterovych@lobbying.in.ua. 
as guidance to decision-makers on how to promote good governance in lobbying. Another international organization, which began to regulate actively the practice of lobbying is the Commonwealth of Independent States. In order to intensify the work concerning legislative regulation of lobbying in the member countries of the CIS, at the XXII Plenary Session of the Interparliamentary Assembly of the CIS member states the Resolution No. 22-16 of November 15, 2003 was adopted, which approved a model law "On regulation of lobbying activity in state authorities".

Keywords: international standards, regulation, lobbying, European Union, Council of Europe, Organisation for Economic Co-operation and Development, Commonwealth of Independent States 


\section{VOLODYMYR NESTEROVYCH}

\section{Międzynarodowe standardy regulacji lobbingu (UE, CE, OECD, CIS)}

\section{Streszczenie}

W artykule przedstawiono międzynarodowe uregulowania dotyczące lobbingu, przyjęte przez cztery organizacje międzynarodowe i ponadnarodowe stowarzyszenia: 1) Unię Europejską; 2) Radę Europy; 3) Organizację Współpracy Gospodarczej i Rozwoju; 4) Wspólnotę Niepodległych Państw.

Główną przyczyną wprowadzenia takich norm na szczeblu międzynarodowym była korupcja przy uchwalaniu aktów prawnych. Stwierdzono, że nieujawniony i nieuregulowany lobbing może poważnie naruszać zaufanie społeczeństwa do instytucji rządowych, zwłaszcza w krajach tzw. nowej demokracji. Międzynarodowe regulacje lobbingu przybierają formę uchwał, przepisów proceduralnych, wytycznych, zaleceń oraz prawodawstwa modelowego.

Warto zauważyć, że pierwsze kroki w kierunku międzynarodowej regulacji lobbingu zostały podjęte przez Unię Europejską. Dzisiejsze uregulowania unijne dotyczące lobbingu są oparte na traktatach założycielskich UE i Karcie Praw Podstawowych. Uregulowania te nie tylko wpływają na ustawodawstwo państw członkowskich UE, lecz także rozciągają się na kraje partnerskie UE.

Rada Europy prowadzi ciągły proces wdrażania międzynarodowych regulacji lobbingu. Przyjęte unormowania znajdują odzwierciedlenie w działalności organów statutowych Rady Europy i ich organów pól-autonomicznych. W ostatnich latach także Organizacja Współpracy Gospodarczej i Rozwoju podjęła prace na rzecz wzmocnienia międzynarodowych norm dotyczących lobbingu. W 2010 roku państwa członkowskie OECD przyjęły zasady dotyczące przejrzystości i uczciwości w działalności lobbingowej - jako wskazówkę, w jaki sposób promować dobre rządy w lobbingu.

Inną międzynarodową organizacją, która aktywnie rozpoczęła normowanie praktyki lobbingu jest Wspólnota Niepodległych Państw. W celu zintensyfikowania prac dotyczących prawnego uregulowania lobbingu w państwach członkowskich WNP, na XXII Sesji Plenarnej Zgromadzenia Międzyparlamentarnego członków WNP w listopadzie 2003 r. przyjęto uchwałę nr 2216 - zatwierdzającą modelowe prawo "O regulacji działalności lobbingowej w organach państwowych". 
Słowa kluczowe: międzynarodowe standardy, regulacje, lobbing, Unia Europejska, Rada Europy, Organizacja Współpracy Gospodarczej i Rozwoju, Wspólnota Niepodległych Państw 
$\mathrm{T}$ oday lobbying is an integral part of the decision-making process. But for quite a long time lobbying was ignored not only by the international regulations, but also by the national legal and industry-specific regulations. In this regard, the view dominated for many years that lobbying is an exclusively American phenomenon of the representation of interests, which may not be suitable for use in other national jurisdictions. But the complications in the modern democratic system and the increasing role of civil society institutions in public and social affairs, have shown clearly that the ideas of lobbying are also suitable for other countries. First, the legal regulation of lobbying at the national level was too slow. In particular, from the 1940s to the early 2000s, only 5 countries (US, Australia, Canada, Germany and Georgia) regulated the practice of lobbying by a special law, which was supplemented by a number of related instruments on the conflict of interest and the rules of ethical behavior of the authorities. ${ }^{2}$

However, since 2005 the process of legal regulation of lobbying has accelerated significantly - more than 10 countries have adopted specific legislation on lobbying. The regulation of this political and legal phenomenon has various models that are based on the features of the national legal systems. The United States of America, Canada, Australia and Germany have extremely detailed regulation of lobbing. By contrast, France and Denmark have adopted rules of regulation of lobbying that are based on a voluntary registration. Many countries, including Britain and Japan rely on the industry-specific self-regulation of lobbying, which is based on ethical codes of lobbying unions and associations. Among other things, conducive to the spreading of the national legislative regulation of lobbying is the development of minimum international standards for the regulation of lobbying adopted by the four international organizations and supranational associations: 1) the European Union; 2) the Council of Europe; 3) the Organization for Economic Cooperation and Development; 4) the Commonwealth of Independent States.

Therefore, today many countries have adopted specific legislation on lobbying. These include the USA, Australia, Canada, France, Germany, Hungary, Israel, Mexico, Georgia, Lithuania, Poland, Slovenia, Montenegro, Austria, Netherlands and Ireland. Many countries have debated over or continue to debate over the draft laws on lobbying. These are Brazil, Chile, Italy, Spain, Great Britain, Latvia,

2 В.Ф. Нестерович, Конституційно-правові засади інституту лобіювання: зарубіжний досвід та перспективи для України, Луганськ 2010, pp. 271-299. 
Estonia, Russia, Ukraine, Moldova, Kazakhstan etc. In addition to the international factors, the experience of legal regulation of lobbying in most countries has shown clearly that such actions were a necessary response of the public authorities to the loud political corruption scandals in the course of lobbying.

On these lines is the opinion of Michael Janssen, a GRECO expert, which pointed out that up until now we lack precise international standards for the demarcation of the unfair exertion of influence on the legislative process by unrestrained/unregulated? lobbying. It's certainly particularly questionable when people who represent particular interest groups are able to exert one-sided influence on the legislative work in ministries and in parliament without this being disclosed and a level playing field guaranteed for all those involved. We can assume that practices like these are very much on the increase internationally - and that democracy is being damaged accordingly. In addition, this kind of exertion of influence should be made a punishable offense if services are rendered in return. ${ }^{3}$

\section{EU standards for the regulation of lobbying}

The first steps towards international regulation of lobbying were taken by the institutions of the European Union. The promotion of the practice of lobbying in institutions of the European Union quite naturally raised the question of regulating this activity. The issue of specialized regulating of lobbying in the European Union was a Written Question tabled by Alman Metten, in 1989. In 1991, Marc Galle, Chairman of the Committee on the Rules of Procedure, the Verification of Credentials and Immunities, was appointed to submit proposals for a Code of conduct and a Register of lobbyists. ${ }^{4}$ The next step towards specialized regulation of lobbying in the European Union was Communiqué of Commission of the European Communities of 4 March 1993. This Communication aimed to implement the commitment contained in the Commission's work programme for 1992, indicating that relations between the Community's institutions and interest groups, useful though they are, must be more clearly defined. ${ }^{5}$

3 M. Janssen, Lobby groups' influence "damaging democracy", Deutsche Welle 2015, January 29, http:// dw.com/p/1ESRB.

4 W. Lehmann, L. Bosche, Lobbying in the European Union: Current Rules and Practices, European Parliament, Working Paper, Constitutional Affairs Series, Luxemburg 2003, p. 36.

5 An open and structured dialogue between the Commission and special interest groups: Commission of the European Communities (1993/C63/02), Official Journal of the European Communities 1993, Vol. 36, p. 2-7. 
Among the EU institutions, it was the European Parliament that in 1996 considered and endorsed the first rules on lobbying. By way of Rules of Procedure 9 (1 and 2), a lobbying registry was set up, together with the College of Quaestors responsible for the implementation of these rules and the issuance of passes to "persons who wished to enter Parliament frequently with a view to supplying information to members within the framework of their parliamentary mandate". These rules became "the cornerstone of the Parliament's policy to regulate the interaction of members of Parliament and private interests". ${ }^{6}$ Since 1999, the European Commission has undertaken a series of transparency-related measures regulating its own administration. They have included the access-to-documents legislation (Regulation 1049/2001) and a register of documents; public access to databases on consultative bodies and experts advising the Commission; wider consultation and impact assessment prior to legislative steps; the Code of Good Administrative Behaviour and the Code of Conduct for Commissioners. ${ }^{7}$

A big role for improving of lobbying regulations was played by the Green Paper on the European Transparency Initiative published in May 2006 and the public consultations which ended in August 2006. The Green Paper defined "lobbying" as all activities carried out with the objective of influencing the policy formulation and decision-making processes of the European institutions. Accordingly, "lobbyists" are defined as persons carrying out such activities, working in a variety of organisations such as public affairs consultancies, law firms, NGOs, think-tanks, corporate lobby units ("in-house representatives") or trade associations. The Green Paper noted that lobbyists can help bring important issues to the attention of the European institutions. In some cases, the Community offers financial support in order to ensure that views of certain interest groups are effectively voiced at the European level (e.g. consumer interests, disabled citizens, environmental interests etc.). ${ }^{8}$

However, European transparency initiative faced strong opposition from business associations and law firms which conduct lobbying in Brussels. A critical moment was reached in late August 2007 when the European Public Affairs Consultancies Association (EPACA), representing 38 major companies, announced that it would boycott the proposed European Commission's voluntary register which

6 Lobbying in a democratic society (European Code of conduct on lobbying): Report Committee on Economic Affairs and Development of 5 June 2009, Council of Europe Parliamentary Assembly, Strasbourg 2009, p. 7.

7 Ibidem, p. 8.

8 Green Paper on the European Transparency Initiative (COM(2006) 194 final), Commission of the European Communities, Brussels 2006, p. 5. 
it labelled as "discriminatory and unworkable". It further claimed that the requirement to disclose "commercially sensitive financial information" (such as client fees) was in breach of EU competition law. Many law firms also said they opposed the register. Moreover, in July 2007, the European ombudsman officially reprimanded EU Trade Commissioner Peter Mandelson for his refusal to name the lobbyists he had met. ${ }^{9}$

After difficult consultations between the European Commission and the lobbyists the first European Commission lobby register was set up on 23 June 2008. The necessity and importance of the register is explained on Transparency Portal. The Portal noted that since decisions taken by the EU affect millions of European citizens, they must be taken as openly as possible. EU institutions interact with a wide range of groups and organisations representing specific interests. This is a legitimate and necessary part of the decision-making process to make sure that EU policies reflect the citizens' real needs. The decision-making process must be transparent to allow for proper scrutiny and to ensure that the Union's institutions are accountable. The European Parliament and the European Commission are committed to being open about the groups and organisations with which they interact. ${ }^{10}$

EU standards for the regulation of lobbying are based on a series of articles set out in the EU-founding treaties and the Charter of Fundamental Rights of the European Union. According to the Treaty of Lisbon: 1) the functioning of the Union is founded on representative democracy. Every citizen has the right to participate in the democratic life of the Union. Decisions must be taken as openly and as closely as possible to the citizen (Article 8A); 2) the institutions must, by appropriate means, give citizens and representative associations the opportunity to make known and publicly exchange their views in all areas of Union action. The institutions must maintain an open, transparent and regular dialogue with representative associations and civil society. The European Commission must carry out broad consultations with the parties concerned in order to ensure that the Union's actions are coherent and transparent (Article 8B). ${ }^{11}$

The possibility of lobbying in the European Union also follows from the Charter of Fundamental Rights of the European Union. The Charter contains those rights and freedoms which are the basis for lobbying in the EU:

$9 \quad$ Lobbying in a democratic society..., op. cit., p. 8.

10 Why a transparency register?, The Transparency Portal, http://bit.ly/21D9Nem.

11 Treaty of Lisbon amending the Treaty on European Union and the Treaty establishing the European Community, signed at Lisbon, 13 December 2007 (2007/C306/01), Official Journal of the European Union 2007, December 17, Vol. 50, p. 15. 
1) everyone has the right to freedom of expression. This right includes freedom to hold opinions and to receive and impart information and ideas without interference by public authority and regardless of frontiers. The freedom and pluralism of the media must be respected (Article 11);

2) everyone has the right to freedom of peaceful assembly and to freedom of association at all levels, in particular in political, trade union and civic matters, which implies the right of everyone to form and to join trade unions for the protection of his or her interests (Article 12);

3) workers or their representatives must, at the appropriate levels, be guaranteed information and consultation in good time in the cases and under the conditions provided for by Community law and national laws and practices (Article 27);

4) workers and employers, or their respective organisations, have, in accordance with Community law and national laws and practices, the right to negotiate and conclude collective agreements at the appropriate levels and, in cases of conflicts of interest, to take collective action to defend their interests, including strike action (Article 28);

5) every person may write to the institutions of the Union in one of the languages of the Treaties and must have an answer in the same language (Article 41);

6) any citizen of the Union, and any natural or legal person residing or having its registered office in a Member State, has a right of access to European Parliament, Council and Commission documents (Article 42);

7) any citizen of the Union and any natural or legal person residing or having its registered office in a Member State has the right to refer to the Ombudsman of the Union cases of maladministration in the activities of the Community institutions or bodies, with the exception of the Court of Justice and the Court of First Instance acting in their judicial role (Article 43);

8) any citizen of the Union and any natural or legal person residing or having its registered office in a Member State has the right to petition the European Parliament (Article 44). ${ }^{12}$

EU standards for the regulation of lobbying influence not only on the EU Member States. These standards also extend to EU Partner Countries in order to help these countries bring national legislation in accordance with European Union Law. In particular, the adoption and ratification of the Association Agreement between

12 Charter of Fundamental Rights of the European Union (2000/C364/01), Official Journal of the European Communities 2000, December 18, pp. 11-19. 
Ukraine and the European Union breathed a new life in the legislative regulation of lobbying in Ukraine and the study of lobbying practices in EU countries. According to Article 444 of the Agreement, the Parties will promote dialogue and cooperation between civil society stakeholders from both sides as an integral part of EU-Ukraine relations, by means of: (a) strengthening of contacts and mutual exchange of experience between civil society organisations in the EU Member States and in Ukraine, in particular through professional seminars, training, etc; (b) facilitating institution-building and consolidation of civil society organisations, including, amongst others, advocacy, informal networking, visits, workshops, etc; (c) enabling the familiarisation of Ukrainian representatives with the process of consultation and dialogue between social and civil partners in the EU, with a view to integrating the civil society into the policy process in Ukraine. ${ }^{13}$

\section{CE standards for the regulation of lobbying}

Significant steps in the implementation of international standards for the regulation of lobbying are constantly being taken by the Council of Europe. The organisation was founded in 1949 and it is a regional intergovernmental organisation whose stated goal is to promote human rights, democracy, and the rule of law in its 47 member states, covering 820 million citizens. According to the Article $1 \mathrm{~b}$ of the Statute of the Council of Europe of 1949 this aim is to be pursued by the organs of the Council through the discussion of questions of common concern and through agreements and common action in economic, social, cultural, scientific, legal and administrative matters and in the maintenance and further enforcement of human rights and fundamental freedoms. ${ }^{14}$

Recently, the statutory bodies of the Council of Europe started to pay closer attention to the regulation of lobbying. Proof of this is provided by the adoption of the Report of 5 June 2009 "Lobbying in a democratic society (European Code of conduct on lobbying)". The Report was prepared by the Committee on Economic Affairs and Development (Rapporteur: Mr. José Mendes Bota, Portugal, Group of the European People's Party). The Report notes that the activities of different interest groups have been constantly increasing at the level of the European insti-

13 Угода про асоціацію між Україною, з однієї сторони, та Європейським Союзом, Європейським співтовариством з атомної енергії і їніми державами-членами, з іншої сторони від 27 червня 2014 року: ратифіковано із заявою Законом Но. 1678 - VII від 16 вересня 2014 року, Офіційний вісник України, 2014, Но. 75, Том 1.

14 Statute of the Council of Europe, 1949, http://bit.ly/1QDgNmC. 
tutions and the Council of Europe member states. However, only four member states had adopted laws on lobbying activities and in ten other member states of the Council of Europe this question has been discussed in the national Parliaments. The rapporteur considers that pluralism of interests is an important element of democracy, but unregulated or secret lobbying may be a danger and can undermine democratic principles and good governance. The draft recommendation proposes a number of principles for the elaboration of a European Code of good conduct on lobbying with a view to improving transparency in this field. ${ }^{15}$

The adoption of CE standards for the regulation of lobbying is reflected in the activity of the statutory bodies of the Council of Europe and its semi-autonomous bodies. These include: 1) the Parliamentary Assembly (PACE); 2) the Committee of Ministers of the Council of Europe; 3 ) the Congress of Local and Regional Authorities; 4) the Conference of International Non-governmental Organisations (INGOs); 5) the European Commission for Democracy through Law (Venice Commission); 6) the Group of States Against Corruption (GRECO). A variety of tasks and the format of activity of the abovementioned bodies of the Council of Europe provides opportunities to develop some comprehensive CE standards for the regulation of lobbying.

European countries are far behind in the legislative regulation of lobbying. Therefore, the Report of the Committee on Economic Affairs and Development of the Parliamentary Assembly of the Council of Europe draws attention to the six factors having bearing on the condition and perspectives of the legal regulation of lobbying in Europe:

1. The Assembly is convinced that pluralism of interests is an important feature of democracy and it is perfectly legitimate for members of society to organise and lobby for their interests. However, unregulated, secret lobbying as such may undermine democratic principles and good governance. In a democracy, all interests ought to be duly taken into account and all citizens should have equal access to the law and decision making.

2. The Assembly notes that very few Council of Europe member states have regulated lobbying activities in any way. Thus surveys have shown that among 14 countries having regulated lobbying or considered the issue within their parliaments, only four European countries have adopted a law on this issue.

3. The Assembly is concerned by the fact that such a situation may undermine democratic principles and good governance in those Council of Europe member states where democratic traditions are not deeply rooted and where

15 Lobbying in a democratic society..., op. cit. 
the absence of effective mechanisms of checks and balances exercised by the civil society constitutes a danger.

4. The Assembly is concerned by the fact that recent decades have witnessed a dramatic decline in public confidence in politics in many Council of Europe member states. The lack of transparency in political and economic lobbying activities can be deemed to constitute one of the causes of this phenomenon.

5. The Assembly is convinced that, in a democratic society, citizens are entitled to know the identity of the lobbying organisations which influence political and economic decision making and voting by members of parliament. Therefore, greater transparency of lobbying activities can make political and economic players even more accountable and restore public confidence in government authorities' democratic functioning.

6. Citizens consider access to political decision makers with a view to providing them with information and attempting to influence their decisions as one of their democratic rights. However, this access or lobbying possibility must be fair and equal, transparent and governed by democratic rules. If citizens do not believe that they can have a real influence on political decision makers, democracy may be undermined. ${ }^{16}$

In addition to the general declarations the Council of Europe began to regulate the institution of lobbying at the level of its statutory bodies. In particular, the Parliamentary Assembly adopted a number of the following acts: 1) Resolution No. 1214 (2000) "Role of parliaments in fighting corruption" (adopted by the Parliamentary Assembly on 5 April 2000 (13th Sitting)); 2) Recommendation No. 1516 (2001) "Financing of political parties" (adopted by the Standing Committee, acting on behalf of the Parliamentary Assembly, on 22 May 2001); 3) Resolution No. 1264 (2001) "Code of good practice in electoral matters" (adopted by the Standing Committee, acting on behalf of the Parliamentary Assembly, on 8 November 2001); 4) Resolution No. 1546 (2007) "The code of good practice for political parties" (adopted by the Parliamentary Assembly on 17 April 2007 (13th Sitting)); 5) Resolution No. 1392 (2004) "Corporate ethics in Europe" (adopted by the Standing Committee, acting on behalf of the Parliamentary Assembly, on 7 September 2004); 6) Resolution No. 1554 (2007) "Conflict of interest" (adopted by the Standing Committee, acting on behalf of the Parliamentary Assembly, on 24 May 2007); 7) Resolution No. 1547 (2007) and Recommendation 1791 (2007) "State of democracy and human rights in Europe" (adopted by the Parliamentary Assembly on 18 April 2007 (15th Sitting)); 8) Resolution 1589 (2007) “Co-operation between the Assembly

$16 \quad$ Ibidem, p. 2. 
and the Conference of INGOs" (adopted by the Standing Committee, acting on behalf of the Parliamentary Assembly, on 23 November 2007; 9) Resolution No.1653 (2009) "Electronic democracy" (adopted by the Parliamentary Assembly on 30 January 2009 (9th Sitting)).

The abovementioned resolutions of the Parliamentary Assembly of the Council of Europe demonstrate the diversity of the phenomenon of lobbying, which has its manifestations virtually in all spheres of public and social life on international, national and local levels. Therefore, the international democratic community does not have easy and fast decisions on the regulation of lobbying. Each such decision requires preliminary examination and approval. Added to this is the likely opposition from the shadow interest groups that are not interested in transparency in lobbying. However, the gradual steps taken by the institutions of the Council of Europe have strengthened the regulation of lobbying.

For instance, the Report "Lobbying in a democratic society (European Code of conduct on lobbying)" states that taking into consideration the importance of the activities of different interest groups in the member States of the Council of Europe, the Assembly recommends that the Committee of Ministers of the Council of Europe should elaborate a European Code of good conduct on lobbying based on the following principles:

1) lobbying should be very clearly defined, differentiating between lobbying as professionally compensated activity and the activities of the organisations of the civil society;

2) ransparency in the field of lobbying should be enhanced;

3) rules applicable to politicians, civil servants, members of pressure groups and business enterprises should be laid down, including the principle of potential conflicts of interest and the period of time after leaving office during which carrying out lobbying activities should be banned;

4) entities involved in lobbying activities should register;

5) prior consultations should be held with lobbying organisations on any draft legislation in this field;

6) well-defined, transparent, honest lobbying should be encouraged so as to improve the public image of persons involved in these activities. ${ }^{17}$

Thus, the European Code of Conduct for lobbyists as one of the number of legislative mechanisms can become an important step in reinforcing transparency, accountability, trust and civic participation of citizens in the democratic process. The presence of extra-legal and informal lobbying in the Council of Europe, despite

17 Ibidem, p. 3. 
the constant practical steps taken by its statutory bodies, indicates a primary need of its adoption. This, in turn, should encourage the member states of the Council of Europe, including Ukraine, which is a member of this authoritative international organization, in the adoption of effective rules on lobbying at the national level.

The Council of Europe recommendations for the regulation of lobbying are particularly useful for the countries of the so-called "new democracy". These recommendations are important guidelines for the development of democratic mechanisms of interaction between the government and society in these countries. However, the problem of regulating lobbying occurs not only in the countries of the so-called "new democracy". Therefore, the recommendation of the Council of Europe for the regulation of lobbying also applies to countries with strong democratic traditions. For example, the Council of Europe's Group of States Against Corruption (GRECO) wants Germany to make lobbyists' influence on the legislative process more transparent.

In 2009 GRECO noted some weaknesses in the transparency and control of the financing of political parties, as well as a series of liability loopholes in the criminal laws dealing with corruption. It therefore recommended, among other things, rectifying the deficiencies in German corruption laws and in the limited criminal liability for bribing members of parliament. The Political Parties Act contains detailed regulations for the political parties' accounting, but it neglects the specific disclosure of election financing. This is not very compatible with international standards, which were set according to the recommendations from the Council of Europe in particular. Among other things, GRECO therefore recommended introducing a system for the early publication of statements of accounts for election campaigns, and improving transparency regarding direct donations to members of parliament and election candidates. It also called for greater strengthening of the resources at the disposal of the president of the lower house of parliament for the monitoring of party financing. In addition, the practice of sponsoring, which is increasingly coming into play, needs to be examined and should ideally acquire a clear legal framework. ${ }^{18}$

\section{OECD standards for the regulation of lobbying}

In recent years, a lot of work on the strengthening of international standards of regulating of lobbying has been done by the Organisation for Economic Co-operation and Development (OECD). It is an international economic organisation of

18 M. Janssen, op. cit. 
34 countries, founded in 1961 to stimulate economic progress and world trade. The mission of the Organisation for Economic Co-operation and Development is to promote policies that will improve the economic and social well-being of people around the world. The OECD provides a forum in which governments can work together to share experiences and seek solutions to common problems. ${ }^{19}$ One of the priorities of the Organisation for Economic Co-operation and Development is fighting corruption in the public sector which includes the regulation of lobbying.

To help address the concerns about transparency and integrity in lobbying, OECD Member Countries adopted in 2010 a Recommendation on Principles for Transparency and Integrity in Lobbying as guidance to decision-makers on how to promote good governance in lobbying. The Principles provide decision makers with directions and guidance on how to foster transparency and integrity in lobbying. Decision makers may use all available regulatory and policy options in order to select measures, guidelines or rules that meet public expectations for transparency and integrity. The Principles are primarily directed at decision makers in the executive and legislative branches. They are relevant to both national and sub-national level.

The Organisation for Economic Co-operation and Development has the following principles for Transparency and Integrity in Lobbying:

I. Building an Effective and Fair Framework for Openness and Access:

1. Countries should provide a level playing field by granting all stakeholders fair and equitable access to the development and implementation of public policies.

2. Rules and guidelines on lobbying should address the governance concerns related to lobbying practices, and respect the socio-political and administrative contexts.

3. Rules and guidelines on lobbying should be consistent with the wider policy and regulatory frameworks.

4. Countries should clearly define the terms "lobbying" and "lobbyist" when they consider or develop rules and guidelines on lobbying.

\section{Enhancing Transparency:}

5. Countries should provide an adequate degree of transparency to ensure that public officials, citizens and businesses can obtain sufficient information on lobbying activities.

19 Lobbyists, Governments and Public Trust, Vol. 3. Implementing the OECD Principles for Transparency and Integrity in Lobbying, Organisation for Economic Co-operation and Development, OECD Publishing 2014 . 
6. Countries should enable stakeholders - including civil society organisations, businesses, the media and the general public - to scrutinise lobbying activities.

\section{Fostering a Culture of Integrity:}

7. Countries should foster a culture of integrity in public organisations and decision making by providing clear rules and guidelines of conduct for public officials.

8. Lobbyists should comply with standards of professionalism and transparency; they share responsibility for fostering a culture of transparency and integrity in lobbying.

\section{Mechanisms for Effective Implementation, Compliance and Review:}

9. Countries should involve key actors in implementing a coherent spectrum of strategies and practices to achieve compliance.

10. Countries should review the functioning of their rules and guidelines related to lobbying on a periodic basis and make necessary adjustments in light of experience. ${ }^{20}$

The above principles harmoniously complement other recommendations of the Council of the Organisation for Economic Co-operation and Development: 1) In Public Procurement [C(2008)105]; 2) On Guidelines for Managing Conflict of Interest in the Public Service [C(2003)107]; 3) On Improving Ethical Conduct in the Public Service [C(98)70/FINAL]; 4) For Enhanced Access and More Effective Use of Public Sector Information [C(2008)36]; 5) On Improving the Quality of Government Regulation [OCDE/GD(95)95]; 6) For Further Combating Bribery of Foreign Public Officials in International Business Transactions [C(2009)159/REV1]; 7) On Guidelines on Corporate Governance of State-Owned Enterprises [C(2005)47]; 8) The OECD Principles of Corporate Governance [C(2004)61]; 9) The OECD Guidelines for Multinational Enterprises [C(2000)96/REV1].

The Recommendation of the Council of the Organisation for Economic Co-Operation and Development on Principles for Transparency and Integrity in Lobbying of 18 February 2010 defines lobbying as oral or written communication with a public official to influence legislation, policy or administrative decisions, often focusing on the legislative branch at the national and sub-national levels. However, it also takes place in the executive branch, for example, in influencing the adoption of regulations or drafts and contracts. Consequently, the term public officials in-

20 Recommendation of the Council of the Organisation for Economic Co-Operation and Development on Principles for Transparency and Integrity in Lobbying of 18 February 2010 (C(2010)16), http://bit.ly/1YveXHb. 
clude civil and public servants, employees and holders of public office in the executive and legislative branches, whether elected or appointed. ${ }^{21}$

For a better understanding of the OECD standards for regulating lobbying, the Organization for Economic Cooperation and Development prepared a series of review papers to study this issue. From among them four key OECD reports are singled out on transparency and integrity in lobbying, viz.:

1. Lobbyists, Governments and Public Trust, Volume 1. Increasing Transparency through Legislation (2009). The report reviews the experiences of Australia, Canada, Hungary, Poland, the United Kingdom and the United States with government regulations designed to increase scrutiny for lobbying and lobbyists. Current approaches, models, trends and state-of-the-art solutions are examined to support a deeper understanding of the potential and limitations of existing norms. The report also presents the building blocks for developing a framework for lobbying that meets the public expectations for transparency, accountability and integrity. ${ }^{22}$

2. Post-Public Employment: Good Practices for Preventing Conflict of Interest (2010). The report provides, in line with identified good practice, guidance to policy makers and managers on how to review and modernise rules, policies and practices for preventing and managing conflict of interest in post-public employment. This report is a contribution of the Public Governance Committee to the efforts of the OECD for cleaner, fairer and stronger economies through mapping governance and corruption risks and developing standards for integrity in the public sector. ${ }^{23}$

3. Lobbyists, Governments and Public Trust, Volume 2. Promoting Integrity through Self-regulation (2012). The report examines the regulation and self-regulation of lobbying. The report includes chapters defining and examining lobbying, describing the role of professional lobbying associations, exploring various codes of conduct and examining specific codes in various countries, examining lobbyists' attitudes toward regulation and self-regulation, and exploring various options for enhancing transparency and accountability. The report also includes the results of a unique survey of lobbyists' attitude in Europe that highlight how existing measures function. ${ }^{24}$

\footnotetext{
21 Ibidem.

22 Lobbyists, Governments and Public Trust, Vol. 1. Increasing Transparency through Legislation, Organisation for Economic Co-operation and Development, OECD Publishing 2009.

23 Post-Public Employment: Good Practices for Preventing Conflict of Interest, Organisation for Economic Co-operation and Development, OECD Publishing 2010.

24 Lobbyists, Governments and Public Trust, Vol. 2. Promoting Integrity through Self-regulation, Organisation for Economic Co-operation and Development, OECD Publishing 2012.
} 
4. Lobbyists, Governments and Public Trust, Volume 3. Implementing the OECD Principles for Transparency and Integrity in Lobbying (2014). The report takes stock of progress made in implementing the 2010 Recommendation on Principles for Transparency and Integrity in Lobbying. The review process found that although there is an emerging consensus on the need for transparency to shed light on lobbying, new regulations are often scandal-driven instead of forward looking. ${ }^{25}$

\section{CIS standards for the regulation of lobbying}

Another international organization, which began to regulate actively the institution of lobbying is the Commonwealth of Independent States. It is a free association of sovereign states formed in 1991 by Russia and 11 other republics that were formerly part of the Soviet Union. In order to intensify the work concerning the legislative regulation of lobbying in the member countries of the CIS, at the XXII Plenary Session of the Interparliamentary Assembly of CIS member states Resolution No. 22-16 of November 15, 2003 was adopted, which approved a model law "On regulation of lobbying activity in state authorities". This document of advisory nature contains the model rules, which give regulatory guidance for national legislation on lobbying. It is not compulsory for the legislative bodies of the CIS member states and is designed primarily to perform the function of specific regulatory and orienting standard.

The main objectives of the model law "On regulation of lobbying activity in state authorities" are: management of relations in the process of lobbying in state authorities; assistance to the implementation of the constitutional rights of citizens to participate personally or through various organizations in public affairs by influencing decision-making process of public authorities; legalization of the promotion of regional, corporate, public, private and other group interests within the government sector; concurrence of interests of different social strata in the activity of state authorities. The subject of the Model Law is lobbying activity in the legislative and executive branches. The implementation of the lobbying activity in the judiciary is not allowed. Deputies and their assistants, officials of the legislative, executive and judicial branches, elected officials of administrative units who are appointed cannot be considered lobbyists and members of parliament. This act does not apply to the experts and consultants that are appointed and invited at

25 Lobbyists, Governments and Public Trust, Vol. 3, op. cit. 
the initiative of the state authorities to give a speech in this authority, as well as to prepare a conclusion on the matter submitted for consideration ${ }^{26}$.

In the CIS model law "On regulation of lobbying activity in state authorities" such sections were incorporated:

1. The key concepts in the field of lobbying: "lobbying activity" is an activity of citizens and their associations entailing establishing contacts with officials and deputies of the legislative branch in order to influence on behalf of and in the interests of specific clients in the development, adoption and implementation by these bodies of legislation, policies, rules, regulations and administrative decisions; "lobbyist" is a citizen, carrying out lobbying for money (fees) or other remuneration on behalf of the third parties, which has passed the state registration and has a power of attorney from the client with the specified powers, as well as an employee organization, whose duties include the implementation of lobbying activity on behalf of and in the interests of the legal person; "lobbying company" is a legal person that has more than one employee in the Post-rated state. Employees act as lobbyists, if their company is not their client; "client" is a citizen, business or nonprofit entity, except for those who have a stake in the share capital of the state, who employs persons engaged in lobbying on their behalf activity. According to this, as it was added to the model law, the legal entity whose staff act as lobbyists on its behalf, is both a client and the employer of the employee; "lobbying contact" is an oral, written, electronic or other message of the client to officials and deputies of public authorities in order to influence the legislative process.

2. The powers of public authorities in the field of lobbying activity, which include: a) formation of government policy in the sphere of the state regulation of the lobbying activity; b) development of draft laws and other regulations governing the lobbying activity; c) monitoring of implementation of the legislation on the lobbying activity.

3. Rights and obligations of lobbyists, their clients:

3.1. Lobbyist has the right to: a) obtain any publicly available information from the relevant government authorities, as well as all the corrections and suggestions on the draft law or another regulation, which is the subject of lobbying. Lobbyist can obtain this information in the lobby-

26 Модельный закон „О регулировании лоббистской деятельности в органах государственной власти": Принят на 22 пленарном заседании МПА государств-участников СНГ (пост. Но. 22-16 от 15 ноября 2003 года), Информационный бюллетень Межпарламентской Ассамблеи государств-участников СНГ, Москва 2004, No. 33, р. 261. 
ist offices of relevant government bodies as a paid service; $b$ ) admission to the executive and legislative branches, their divisions and departments, the possibility of meetings with the deputies and officials in accordance with the above mentioned authorities; c) transfer of information and analytical materials for consideration to the state authorities, as well as suggestions on legislative, political and administrative decisions. It should be noted that this law clearly indicates that the failure to review and to accept submissions is not allowed; d) to appeal judicially against the actions of officials.

3.2. The duties of the lobbyist are: a) registration with the tax authority in the community as a sole proprietor who provides consulting services, or provide a certificate issued by a legal entity - the employer, about his staying in the state; b) registration with the Ministry of Justice and obtaining a license for the lobbying activity; c) accreditation with the body which is planning to carry out lobbying; $d$ ) in case where the client (employer) is a lobbyist for a foreign person, if the treaty was signed by the parties, within five days report it to the Ministry of Justice and verify receipt of this information; e) to submit information about registration in the Ministry of Justice, including the date of registration and license number of the official who comes into lobbying contact; e) submit reports on the results in the established order.

3.3. Rights and obligations of the client. The client is entitled to qualified representation of his interests by the lobbyist in the government according to the generally accepted rates or by mutual agreement. But the client must not interfere with the ongoing activity of the lobbyist, carrying out the functions of control and acceptance or rejection of the results of the work done by compiling a relevant act. He is obliged to inform the Ministry of Justice and the tax authorities on the expenditure and recipients of the client in writing at their place of registration within thirty days after their implementation. Expenditures on lobbying relate to the balance sheet of the client "The cost of works and services".

4. Registration and accreditation of lobbyists, which is carried out by the Ministry of Justice on the basis of the corresponding application filed by a person and as a result of which the Ministry of Justice issues a license for the lobbying activity. In a statement the person must provide the following information: surname, first name, date of birth, passport number, principal place of business (if any), education, home address and telephone number or other means of communication, legislative interest, if any already exist. 
Entity (a lobbying company) produces notarized copies of constitutive documents and lists of citizens who are the employees, with all their data listed in the first part of this article. The legal entity is responsible for the accuracy of the data presented in accordance with applicable law. A citizen's application is considered by the Ministry of Justice within twenty days. In the absence of restrictions a person obtains a temporary license within five days (free of charge, valid for one month), after receiving of which a lobbyist has the right to start lobbying. During the term of the temporary license the lobbyist must be registered as an individual entrepreneur with the tax authority in the community. Registration entrepreneur sole trader is not required if he is an employee of a legal entity - the employer or a lobbying company.

After the expiration of the temporary license and obtaining a patent on the business activity, a citizen calls to the Ministry of Justice, which checks the alleged by the lobbyist statements during ten days, gives the citizen a permanent license, which is valid for three years. The license may be extended by the Ministry of Justice in case where within thirty days prior to the end of validity the lobbyist applies for the extension of the lobbying activity. After registering a person as a lobbyist, according to the Model Law, he must be accredited by the bodies where he plans to carry out lobbying. The Model law calls them the House of Parliament, Government and Presidential Administration.

5. Methods of lobbying activity: a) presentation of information, documents, drafts, administrative and policy decisions on matters within the scope of the said bodies to the officials of state authorities; b) participation at the request of lobbyist in the committees, commissions, factions and deputy groups and other agencies of the legislative body and organs of executive power on the range of issues lobbied with the permission of these bodies; c) establishment of lobbying contacts with members and officials of public authorities to promote the interests of their clients; d) efforts to support the establishment of contacts, reflected in the requests for meeting, invitation to social events to promote interests of a client; e) organization of publications and speeches in the media in support of or against specific legislation or decisions of public authorities. The above list of lobbying techniques is not exhaustive, the use of other, not prohibited by applicable law practices, is possible.

6. The form and terms of reporting by lobbyists. In particular, lobbyists' reports contain the following: a) information about the customers with indication of their legal details, including the identification codes of the State Statistics 
Committee; b) all the material resources provided by them, including temporary use, in an amount not less than one minimum salary; c) legislative interest of the client; d) expenses and their acceptors; e) the results achieved; g) the public authorities which came into lobbying contacts. According to this, a lobbyist is required to submit to the Ministry of Justice the report on his activity no later than one month after the end of each calendar semester, and after the completion of his work. Reporting of the lobbyist to the tax authorities is regulated by current legislation on the procedure of accounting.

7. Liability for violation of legislation on lobbying activities. Penalties are defined in different sizes depending on the severity of the offense, suspension of accreditation or licensing. Persons engaged in lobbying activities without registration may be held liableby the court at the suit of the Ministry of Justice. Responsibility of a lobbyist to the client is determined by agreement to provide services between them. All disputes between the lobbyist and the client are resolved in the courts. ${ }^{27}$

Thus, the international regulation of lobbying is increasingly taking the form of generally recognized standards. Four international organizations and supranational associations, such as the European Union, the Council of Europe, the Organization for Economic Cooperation and Development and the Commonwealth of Independent States have introduced these standards. The main reason for the adoption of international standards for the regulation of lobbying is considerable corruption in the adoption of legal acts. The latent and unregulated lobbying can seriously undermine public confidence in the institution of government, especially in the countries of the so-called "new democracy". International regulation of lobbying takes the form of resolutions, procedural rules, guidelines, recommendations and model legislation.

\section{Bibliography}

An open and structured dialogue between the Commission and special interest groups: Commission of the European Communities (1993/C63/02), Official Journal of the European Communities 1993, Vol. 36.

Charter of Fundamental Rights of the European Union (2000/364/01), Official Journal of the European Communities 2000, December 18.

$27 \quad$ Ibidem, pp. 261-272. 
Green Paper on the European Transparency Initiative, COM(2006) 194 final, Commission of the European Communities, Brussels 2006.

Janssen M., Lobby groups' influence "damaging democracy", Deutsche Welle 2015, January 29, http://dw.com/p/1ESRB.

Lehmann W., Bosche L., Lobbying in the European Union: Current Rules and Practices, European Parliament, Working Paper, Constitutional Affairs Series, Luxemburg 2003.

Lobbying in a democratic society (European Code of conduct on lobbying): Report Committee on Economic Affairs and Development of 5 June 2009, Council of Europe Parliamentary Assembly, Strasbourg 2009.

Lobbyists, Governments and Public Trust, Vol. 1, Increasing Transparency through Legislation, Organisation for Economic Co-operation and Development, OECD Publishing 2009.

Lobbyists, Governments and Public Trust, Vol. 2, Promoting Integrity through Self-regulation, Organisation for Economic Co-operation and Development, OECD Publishing 2012. Lobbyists, Governments and Public Trust, Vol. 3, Implementing the OECD Principles for Transparency and Integrity in Lobbying, Organisation for Economic Co-operation and Development, OECD Publishing 2014.

Модельный закон „О регулировании лоббистской деятельности в органах государственной власти": Принят на 22 пленарном заседании МПА государств-участников СНГ (пост. Но. 22-16 от 15 ноября 2003 года), Информационный бюллетень Межпарламентской Ассамблеи государств-участников СНГ, Москва 2004, No. 33, p. 261.

Нестерович В.Ф., Конституційно-правові засади інституту лобіювання: зарубіжний досвід та перспективи для України, Луганськ 2010.

Post-Public Employment: Good Practices for Preventing Conflict of Interest, Organisation for Economic Co-operation and Development, OECD Publishing 2010.

Recommendation of the Council of the Organisation for Economic Co-Operation and Development on Principles for Transparency and Integrity in Lobbying of 18 February 2010 (C(2010)16), http://bit.ly/1YveXHb

Statute of the Council of Europe, 1949, http://bit.ly/1QDgNmC

Treaty of Lisbon amending the Treaty on European Union and the Treaty establishing the European Community, signed at Lisbon, 13 December 2007 (2007/C306/01), Official Journal of the European Union 2007, December 17, Vol. 50.

Угода про асоціацію між Україною, з однієї сторони, та Європейським Союзом, Свропейським співтовариством з атомної енергії і їхніми державами-членами, з іншої сторони від 27 червня 2014 року: ратифіковано із заявою Законом Но. 1678 - VII від 16 вересня 2014 року, Офіційний вісник України 2014, Но. 75, Том 1.

Why a transparency register?, The Transparency Portal, http://bit.ly/21D9Nem 